\title{
Ni-modified magnetic nanoparticles for affinity purification of His-tagged proteins from the complex matrix of the silkworm fat body
}

\author{
Robert Minkner ${ }^{1,2 \dagger}$, Jian $\mathrm{Xu}^{3,4 \dagger}$, Kenshin Takemura ${ }^{1 \dagger}$, Jirayu Boonyakida ${ }^{1}$, Hermann Wätzig ${ }^{2}$ \\ and Enoch Y. Park ${ }^{1,3^{*}}$ (D)
}

\begin{abstract}
Purification of recombinant proteins is often a challenging matter because high purity and high recovery are desired. If the expressed recombinant protein is also in a complex matrix, such as from the silkworm expression system, purification becomes more challenging. Even if purification from the silkworm expression system is troublesome, it benefits from a high capacity for the production of recombinant proteins. In this study, magnetic nanoparticles (MNPs) were investigated as a suitable tool for the purification of proteins from the complex matrix of the silkworm fat body. The MNPs were modified with nickel so that they have an affinity for His-tagged proteins, as the MNP purification protocol itself does not need special equipment except for a magnet. Among the three different kinds of investigated MNPs, MNPs with sizes of $100 \mathrm{~nm}$ to $200 \mathrm{~nm}$ and approximately $20 \mathrm{~nm}$-thick nickel shells were the most suitable for our purpose. With them, the total protein amount was reduced by up to at least approximately $77.7 \%$, with a protein recovery of around $50.8 \%$ from the silkworm fat body. The minimum binding capacity was estimated to be $83.3 \mu \mathrm{g} \mathrm{protein} / \mathrm{mg}$ MNP. Therefore, these MNPs are a promising tool as a purification pretreatment of complex sample matrices.
\end{abstract}

Keywords: Magnetic nanoparticles, Affinity purification, Recombinant protein, Silkworm, Magnetic separation

\section{Introduction}

Usually, for protein production, Escherichia coli or yeast systems are mainly utilized because they are already well established, and their advantages are known. However, low protein quality or the inability to generate posttranslational modifications are typical disadvantages [1]. However, another interesting option for us is using the larvae of the domestic silkworm, Bombyx mori, as a recombinant protein expression system. Because this system is

\footnotetext{
*Correspondence: park.enoch@shizuoka.ac.jp

${ }^{\dagger}$ Robert Minkner, Kenshin Takemura, and Jian Xu contributed equally.

1 Department of Bioscience, Graduate School of Science and Technology, Shizuoka University, 836 Ohya, Suruga-ku, Shizuoka 422-8529, Japan

Full list of author information is available at the end of the article
}

a eukaryotic insect cell system, the silkworm expression system provides the same posttranslational modifications as insect cell lines. For specific proteins, an even higher production yield than achieved with the systems mentioned above can be achieved [1-6]. In the system, the injected recombinant Bombyx mori nucleopolyhedrovirus (BmNPV) bacmid infects the larvae's cells, which then start to express the desired recombinant proteins. Depending on the expressed protein, the protein will remain inside the cells or released into the hemolymph [2].

The silkworm contains abundant host proteins. These proteins make purification from the silkworm extremely challenging [1]. Moreover, lipid content in silkworm tissues, such as the fat body, is also abundant compared to 
that in other hosts used for protein expression $[7,8]$. Usually, for purification from this system, traditional sucrose gradient density centrifugation and affinity purification are used, but generally, they have not been explored for optimization [9-11]. Approaches to improving purification with this system solely based on standard methods also present challenges [12]. Currently, no broadly practical purification approach is available for the purification of proteins from silkworms, except for some exceptional cases in which the host proteins are abundant and diverse. The silkworm expression system is an example of a complex sample matrix. Therefore, purification from this system is still a bottleneck for the use of this expression system as it was already reviewed [7], and we could show that the purification is indeed not easy $[12,13]$. Therefore, we will not discuss this aspect exhaustively any further in this paper.

Nanoparticles or magnetic nanoparticles (MNPs) are currently an emerging technology in many scientific fields. These nanomaterials display several advantages because of their nanosize, which is approximately $10-100 \mathrm{~nm}$. They can be used for magnetic resonance imaging, targeted drug delivery, targeted destruction of cancer through hyperthermia, magnetic transfection, tissue engineering, or purification [14, 15]. MNPs can be produced through different methods, including grinding, thermal decomposition, microemulsion, chemical vapor deposition, coprecipitation, a reaction in a constrained environment, the polyol method, flow-injection synthesis, and sonolysis [14, 16-18]. Methods for further surface modification have not been incorporated yet and are performed to modulate solubility, stability, internalization, or toxicity $[14,16,17,19]$. One of the most commonly used coating materials utilizes silica because of its efficiency, reduced toxicity, aggregation prevention, and hydrophilicity $[14,19]$. In terms of toxicity, it is commonly assumed that iron nanoparticles are noncytotoxic and safe for use at a concentration of $100 \mu \mathrm{g} / \mathrm{ml}[16,20]$. Moreover, they can be cleared by the endogenous iron metabolic pathway, leading to incorporation into hemoglobin [16]. The relative non-toxicity makes iron nanoparticles attractive not only for medical purposes but also for downstream biotechnological processes because they don't need to be removed under certain circumstances in some products.

It is then reasonable to assume that MNPs are a viable option to purify recombinant proteins. Purification can be performed in two ways: direct binding of the target protein or by removing unwanted proteins. It was shown that the latter could be a safe and effective way to remove haze-forming proteins from wines [21]; the surfaces of the MNPs were modified with an amine, carboxyl, or oxazoline functional groups. Silica-coated iron magnetic nanoparticles functionalized with a nickel shell were used to remove the abundant protein hemoglobin from bovine blood [19]. Nickel has a high affinity for the His-tag and proteins with a high number of histidine residues. Therefore, bovine hemoglobin was successfully and selectively reduced, even if the level of reduction in the diluted bovine blood sample was low due to protein-protein interactions [19].

Another method involves modification of the MNPs to such an extent that they can specifically separate the target protein. These modifications do not necessarily need to be antibodies, as adamantane beta-cyclodextrin $(\beta-C D)$ was used to modify MNPs, which were then able to bind the target lectin [22]. This construct was able to separate concanavalin A from a mixture containing peanut agglutinin. The elution was performed by adding mannose as a competitive ligand [22]. Ta et al. [23] modified MNPs in a modular fashion so that they were able to separate the targeted biomarkers, even if they were displayed on whole eukaryotic cells. This modularity also allows the rapid switching of the receptor on the MNPs to target different biomarkers [23].

Another method involves the design of the protein to enhance compatibility with the MNP. A peptide tag of six glutamates proved to be very useful for binding bare iron oxide nanoparticles (BIONs) [24]. It could even be used for purification on an industrial scale to generate BIONs that could achieve a mean recovery of $81 \%$ [24]. Of course, the MNPs can be modified to be compatible with already existing protein tags. Jose et al. [25] encapsulated $\mathrm{Fe}_{3} \mathrm{O}_{4}$ nanoparticles in polystyrene nanoparticles and functionalized them with $\mathrm{Ni}^{2+}$-nitrilotriacetic (NTA) to purify a His-tagged model protein. These particles were even more efficient than the already commercially available $\mathrm{Ni}^{2+}$-NTA-magnetic beads [25]. In a study similar to our conducted research, bare iron oxide nanoparticles were used, and His-tagged green fluorescent protein (GFP) was purified as a model protein; the most complex sample matrix was an E. coli cell lysate [26]. However, the study demonstrated the usage of high-gradient magnetic fishing with an electromagnet, $1 \mathrm{~L}$ crude cell lysate, and a system with a capacity of $2 \mathrm{~L}$.

Because such MNPs are such intriguing materials in terms of their uses, they are already commercialized. However, these commercialized products are not costeffective, especially when purification must be performed on at least a milliliter scale. Therefore, they are constantly further investigated and improved [27-29]. We tried to purify recombinant proteins from complicated and hard-to-purify matrices using a simple and easy pretreatment step to purify His-tagged recombinant proteins. One option to achieve this could be to generate such MNPs in the laboratory when needed. 
Therefore, our study focused on the preparation of magnetic nanoparticles, which are inexpensive, easily made in the laboratory, and disposable. Three different kinds of particles were tested to determine their usability for purification, and one of them proceeded to be utilized for further investigations. This particle was able to purify a model fluorescent protein from an E. coli cell lysate with high purity and to achieve high recovery of the target proteins from the complex silkworm fat body sample as a pretreatment step. Moreover, these nanoparticles have a significantly higher binding capacity than a commercial product with a similar elution capability, as we will show in this study.

\section{Materials and methods}

If not mentioned otherwise, all materials and reagents, such as tetraethyl orthosilicate, $\mathrm{FeCl}_{2}, \mathrm{FeCl}_{3}$, (3-aminopropyl)trimethoxysilane, and $\mathrm{Ni}(\mathrm{OAc})_{2}$, were purchased from Sigma-Aldrich (Tokyo, Japan). Ammonium hydroxide was purchased from Wako Pure Chemical Ind. Ltd. (Osaka, Japan).

\section{Plasmid preparation and expression of SpyCatcher-mCherry-SpyTag in E. coli}

The mCherry DNA fragment was subcloned from the plasmid pmCherry (Catalog \# 632522, TakaraBio, Japan) using specific primers (mCherryFw: $5^{\prime}$-gtgagcaagggcgaggaggat- $3^{\prime}$; mCherryRv: 5'-cttgtacagctcgtccatgcc-3') into pFastBac-SpyCatcher/SpyTag [30] and was designated pFB-SC-mCherry-ST. The recombinant plasmid consisted of a His tag, StrepTag II, SpyCatcher, SpyTag, and tobacco etch virus (TEV) protease cleavage sites. The plasmid was used as a template for amplifying the whole gene sequence using primers (Cat-FW: $5^{\prime}$-atgcaccaccaccaccatcaccatcac-3', pFastBac-RV: $5^{\prime}$-acaaatgtggtatggctgatt- $3^{\prime}$ ) and subsequently subcloned into pET-41a (+) (Novagen, Tokyo, Japan), and the resulting construct was designated pET41SC-mCherry-ST. The recombinant plasmid was electroporated into Rosetta-gami 2(DE3) E. coli (Novagen, Tokyo, Japan) to express the recombinant mCherry protein.

For the expression of SC-mCherry-ST, E. coli Rosettagami $^{\text {TM }}$ 2(DE3)/pET41-SC-mCherry-ST were inoculated into $1 \mathrm{~L}$ of Luria-Bertani medium (LB broth, Invitrogen, Thermo Fisher Scientific, Tokyo, Japan) containing $25 \mu \mathrm{g} /$ $\mathrm{mL}$ kanamycin and incubated at $37{ }^{\circ} \mathrm{C}$ until the $\mathrm{OD}_{600}$ reached 0.5 . Then, protein expression was induced by adding isopropyl $\beta$-D-1-thiogalactopyranoside (IPTG) at a final concentration of $0.5 \mathrm{mM}$, followed by incubation at $16{ }^{\circ} \mathrm{C}$ for $16 \mathrm{~h}$. Subsequently, the cells were collected by centrifugation $\left(6000 \times g, 4{ }^{\circ} \mathrm{C}, 15 \mathrm{~min}\right)$, washed twice with ice-cold phosphate-buffered saline (PBS, $\mathrm{pH}$ 7.3), and stored at $-80^{\circ} \mathrm{C}$ before use.

\section{Recombinant B. mori nucleopolyhedrovirus (BmNPV) bacmid preparation for SpCaVP1 and EDIII}

The Norovirus VP1 DNA fragment was subcloned into the pFastBac-SpyCatcher plasmid [24] from a recombinant Autographa californica nucleopolyhedrovirus (AcMNPV) kindly provided by Dr. Tian-Cheng Li (Department of Virology 2, National Institute of Infectious Diseases, Musashimurayama, Japan). The DNA sequence also encoded poly-tags (His-Strep-TEV-NoroVP1-SpyCatcher) and consisted of a His-tag, a Streptag II, a TEV protease cleavage site, and a SpyCatcher. The resulting plasmid for expressing the $\mathrm{SpCaVP} 1$ protein was designated pFastBac-HSSc-SpCaVP1. The codon-optimized EDIII DNA fragment was synthesized (Genewiz, Suzhou, China) based on the sequence of Dengue virus 1 (GenBank No. KM204119). The EDIII sequence was then amplified using primers (1DIII-Fw: 5'-agttatgttatgtgcaccgg-3'; 1DIII-Rv: 5'-gcccaaaatagccattcgcc- $3^{\prime}$ ) and further ligated into pFastBac-cSpyTag [24]. The DNA sequence also encoded poly-tags (an EDIII-cSpyTag-TEV-Strep-Flag, SpyTag, TEV protease cleavage site, Strep-Tag, and Flag-Tag). The resulting plasmid for expressing the EDIII protein was designated pFastBac-FSS-EDIII. Both plasmids were constructed and then utilized for the generation of a recombinant BmNPV bacmid. Subsequently, the recombinant baculovirus was generated in cultured $\mathrm{Bm} 5$ cells according to our previous reports [31]. The cell culture supernatant was collected and used for serial infections to obtain high-titer virus stocks, which were employed to infect silkworm larvae.

\section{Expression of recombinant proteins from silkworms}

Fifth instar silkworm larvae (Ehime Sansyu, Ehime, Japan) were reared on an artificial diet (Silkmate S2, Nosan, Yokohama, Japan) in a rearing chamber (MLR$351 \mathrm{H}$, Sanyo, Moriguchi, Japan) at $25{ }^{\circ} \mathrm{C}$. On the second day, the 5th instar larvae were injected with $10 \mu \mathrm{l}$ of a PBS solution containing $250 \mu \mathrm{l} / \mathrm{ml}$ recombinant baculovirus stock using a $1 \mathrm{ml}$ syringe $(26 \mathrm{G} \times 1 / 2$, $0.45 \times 13 \mathrm{~mm}$ ). Five days postinjection (dpi), the fat body was collected in $5 \mathrm{ml}$ lysis buffer $(0.2 \mathrm{~mol} / \mathrm{l}$ Tris$\mathrm{HCl}, \mathrm{pH} 7.6,0.1 \%$ IGEPAC, and protease inhibitor) from each silkworm. This solution was sonicated as follows: $10 \mathrm{~s}$ at an amplitude of $60-80$ with $30 \mathrm{~s}$ on ice for each cycle, which was repeated 20 times. The sonicated solution was incubated on ice for $1 \mathrm{~h}$ and centrifuged at $4{ }^{\circ} \mathrm{C}$ and $8000 \times g$ for $15 \mathrm{~min}$. The supernatant was 
filtered with a $0.2 \mu \mathrm{m}$ filter and stored at $-80{ }^{\circ} \mathrm{C}$ until use.

\section{Lysis of recombinant protein expressed in E. coli (mCherry construct)}

The $E$. coli cell pellet was resuspended in $3 \mathrm{ml}$ ice-cold PBS for each $50 \mathrm{ml}$ culture. To a $15 \mathrm{ml}$ solution, $15 \mu \mathrm{l}$ of $1 \mu \mathrm{g} / \mathrm{ml}$ lysozyme and $15 \mu \mathrm{l} 1 \times$ complete Mini EDTA free Version protease inhibitor (from a $100 \times$ stock solution, Roche, Tokyo, Japan) was added and incubated on ice for $30 \mathrm{~min}$. Sonication was performed on the ice at an amplitude of 70 with a 30 -s interval cycle for $20 \mathrm{~min}$. This solution was then centrifuged at $12,000 \times g$ for $10 \mathrm{~min}$ at $4{ }^{\circ} \mathrm{C}$. The supernatant was filtered with a $0.2 \mu \mathrm{m}$ filter before further use.

\section{Preparation of Ni-conjugated magnetic nanoparticles (Ni-MNPs)}

The superparamagnetic iron oxide nanoparticles (SPIONs) were synthesized by following Massart's method [32]. Five milliliters of ammonium hydroxide were added to $5 \mathrm{mmol}$ of $\mathrm{FeCl}_{2}$ and $10 \mathrm{mmol}$ of $\mathrm{FeCl}_{3}$ in $40 \mathrm{ml}$ of ultrapure water. The mixed solution was vigorously stirred at room temperature for $30 \mathrm{~min}$, and the synthesized MNPs were magnetically separated from the solution. Subsequently, the synthesized MNPs were coated with $\mathrm{SiO}_{2}$ for functionalization and stabilization [33]. The freshly synthesized SPIONs in $120 \mathrm{ml}$ ethanol were sonicated at room temperature for $30 \mathrm{~min}$, and $150 \mu \mathrm{l}$ of tetraethyl orthosilicate (TEOS) was added to the solution. The MNP@SiO $\mathrm{Sis}_{2}$ waparated and washed at room temperature after $6 \mathrm{~h}$ of stirring.

Amino group conjugation for MNP functionalization was performed by following previously reported protocols [34]. The washed $\mathrm{MNP} @ \mathrm{SiO}_{2}$ was dissolved in $100 \mathrm{ml}$ anhydrous toluene, sonicated for $30 \mathrm{~min}$, and then loaded into a three-necked round-bottom flask. (3-Aminopropyl)trimethoxysilane (APTMS) was added slowly and heated at $40{ }^{\circ} \mathrm{C}$ with vigorous stirring for $24 \mathrm{~h}$. The product was magnetically separated and washed with ethanol several times.

Ni-modified $\mathrm{MNP} @ \mathrm{SiO}_{2} @ \mathrm{NH}_{2}$ was prepared as previously reported [35]. Briefly, $0.32 \mathrm{~g}$ of isatoic anhydride was added to the solution, and $0.5 \mathrm{~g}$ of amino benza-

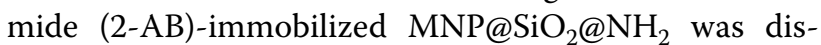
solved in $100 \mathrm{ml}$ of anhydrous toluene and refluxed for

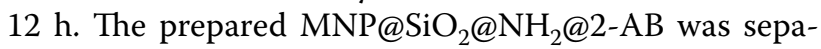
rated by magnetic decantation and washed with ethanol several times. $\mathrm{MNP} @ \mathrm{SiO}_{2} @ \mathrm{NH}_{2} @ 2-\mathrm{AB}(0.5 \mathrm{~g})$ was suspended in $100 \mathrm{ml}$ of ethanol and ultrasonically dispersed to form a homogeneous solution mixed with $2 \mathrm{mmol}$ $\mathrm{Ni}(\mathrm{OAc})_{2} \cdot 4 \mathrm{H}_{2} \mathrm{O}$ and refluxed for $12 \mathrm{~h}$. The Magnetically separated $\mathrm{MNP} @ \mathrm{SiO}_{2} @ \mathrm{NH}_{2} @ \mathrm{Ni}$ was washed with ethanol to remove unreacted agents and dried overnight.

Each sample was characterized using transmission electron microscopy (TEM; JEM-2100F, JEOL, Ltd., Tokyo, Japan) with energy dispersive X-ray spectrometry (EDS) for elemental mapping nickel and iron. The zeta potential and hydrodynamic particle size were measured by dynamic light scattering (DLS) using a Zetasizer Nano series (Malvern Inst. Ltd., Malvern, UK).

\section{Strep-tag affinity chromatography}

Purification of mCherry from the $E$. coli cell lysate was performed using the Strep-Tactin affinity column with a manual peristaltic pump at a low flow rate $(0.5 \mathrm{ml} / \mathrm{min})$. The processed lysate was filtered through a $0.8 \mu \mathrm{m}$ filter before chromatography was performed. The elution fraction, which had a reddish/purple color and strong red fluorescence, was separately collected.

\section{General MNP purification protocol}

Purification with the commercial magnetic bead MagneHis (Promega, Tokyo, Japan) was performed according to the manufacturer's manual, but the amounts used varied depending on the scale. Usually, the $\mathrm{Ni}$ particles were vortexed before usage, and then 100-300 $\mu$ l of particles ( $2 \mathrm{mg} / \mathrm{ml} \mathrm{MNP}$ solution) were added to a $1 \mathrm{ml}$ sample. Incubation was performed for $10 \mathrm{~min}$ after mixing, but the mixture was stirred for $2 \mathrm{~h}$ at $4{ }^{\circ} \mathrm{C}$ for scaling up. For the magnetic separation a neodymium magnet (TRUSCO Nakayama, Tokyo, Japan) was used. The supernatant was removed, and $500 \mu \mathrm{l}$ washing buffer $(100 \mathrm{mmol} / \mathrm{l}$ HEPES and $10 \mathrm{mmol} / \mathrm{l}$ imidazole) was added and mixed. After magnetic separation, the previous step was repeated two times. For elution, $200 \mu \mathrm{l}$ elution buffer $(100 \mathrm{mmol} / \mathrm{l}$ HEPES and $500 \mathrm{mmol} / \mathrm{l}$ imidazole) was used. A different buffer $(20 \mathrm{mmol} / \mathrm{l}$ Tris- $\mathrm{HCl}, 0.5 \mathrm{~mol} / \mathrm{l} \mathrm{NaCl}$ and $1 \mathrm{~mol} / \mathrm{l}$ imidazole, $\mathrm{pH}$ 7.5) was applied to ensure complete elution.

For the MNPs prepared, as described in "2.5" section, the volume of sample/buffers/MNPs used varied in each protocol. In most cases, only two elution steps were performed. The basic sequence of the protocols was as follows. The MNPs were sonicated in a water bath for $30 \mathrm{~min}$, and $350 \mu \mathrm{l}$ of $2 \mathrm{mg} / \mathrm{ml}$ solution of MNPs were added to $250 \mu \mathrm{l}$ of sample and $200 \mu \mathrm{l}$ of washing buffer (20 mmol/l Tris- $\mathrm{HCl}, 0.5 \mathrm{~mol} / \mathrm{l} \mathrm{NaCl}$ and $20 \mathrm{mmol} / \mathrm{l} \mathrm{imi-}$ dazole, $\mathrm{pH}$ 7.5). These were mixed and then incubated on ice for $30 \mathrm{~min}$ with occasional gentle mixing. After magnetic separation, the supernatant was removed, $200 \mu \mathrm{l}$ washing buffer was added, and the mixture was incubated on ice for $10 \mathrm{~min}$. After magnetic separation was performed 2 times, following buffers were used for elution: a weak elution buffer $(20 \mathrm{mmol} / \mathrm{l}$ Tris $-\mathrm{HCl}, 0.5 \mathrm{~mol} / \mathrm{l}$ 
$\mathrm{NaCl}$ and $300 \mathrm{mmol} / \mathrm{l}$ imidazole, $\mathrm{pH}$ 7.5), a strong elution buffer $(20 \mathrm{mmol} / \mathrm{l}$ Tris-HCl, $0.5 \mathrm{~mol} / \mathrm{l} \mathrm{NaCl}$, or $1 \mathrm{~mol} / \mathrm{l}$ imidazole, $\mathrm{pH}$ 7.5). The amount depended on the protocol. The incubation time was $30 \mathrm{~min}$ on ice with occasional gentle mixing. After magnetic separation, the previous step was repeated with a strong elution buffer. For the volumes of the individual purification protocols, which are variable or not mentioned here, please see the figure legends which contain the specific information for the respecting figure. For all magnetic separations, the time to attract all MNPs were at least $5 \mathrm{~min}$, as the case may also be longer, to ensure that all MNPs settled.

\section{Optimized MNP3 purification protocol}

The MNPs were sonicated in a water bath for $30 \mathrm{~min}$, and $2 \mathrm{ml}$ of $3.75 \mathrm{mg} / \mathrm{ml} \mathrm{MNPs}$ were added to $1 \mathrm{ml}$ fat body sample and $600 \mu \mathrm{l}$ washing buffer $(20 \mathrm{mmol} / \mathrm{l}$ Tris $-\mathrm{HCl}$, $0.5 \mathrm{~mol} / \mathrm{l} \mathrm{NaCl}$, and $20 \mathrm{mmol} / \mathrm{l}$ imidazole, $\mathrm{pH}$ 7.5). These were mixed and then incubated on ice for $30 \mathrm{~min}$ with occasional additional mixing. After magnetic separation, the supernatant was removed, $200 \mu \mathrm{l}$ washing buffer was added, and the mixture was incubated for $10 \mathrm{~min}$ on ice. After magnetic separation, the washing step was repeated. After magnetic separation was performed during the first elution step, $500 \mu \mathrm{l}$ of weak elution buffer $(20 \mathrm{mmol} / \mathrm{l}$ Tris- $\mathrm{HCl}, 0.5 \mathrm{~mol} / \mathrm{l} \mathrm{NaCl}$, and $300 \mathrm{mmol} / \mathrm{l}$ imidazole, $\mathrm{pH}$ 7.5) was used. For the second elution step, $500 \mu \mathrm{l}$ of strong elution buffer $(20 \mathrm{mmol} / \mathrm{l}$ Tris-HCl, $0.5 \mathrm{~mol} / \mathrm{l} \mathrm{NaCl}$, and $1 \mathrm{~mol} / \mathrm{l}$ imidazole, $\mathrm{pH} 7.5$ ) was used. As the third elution step, the second elution step was repeated. The incubation was performed for $30 \mathrm{~min}$ on ice with occasional additional mixing. For all magnetic separations, the time to attract all MNPs were at least $5 \mathrm{~min}$, as the case may also be longer, to ensure that all MNPs settled.

\section{SDS-PAGE}

The samples were investigated using $10 \%$ polyacrylamide gels. They were diluted with an equal amount of sample buffer $(0.125 \mathrm{~mol} / \mathrm{L}$ Tris-HCl, $4 \%$ SDS, $20 \%$ glycerol, $0.01 \%$ mercaptoethanol, and $0.15 \mathrm{mmol} / \mathrm{L}$ bromophenol blue), mixed, and heated at $95{ }^{\circ} \mathrm{C}$ for $5 \mathrm{~min}$ for denaturation. Electrophoresis was carried out with a BioRad SDS-PAGE chamber with a PowerPac Basic (BioRad, Hercules, CA, USA). The constant voltage was set at $90 \mathrm{~V}$ for the stacking gel and $120 \mathrm{~V}$ for the running gel. The size classification was performed with the PM1700 ExcelBand standard (Smobio, Hsinchu City, Taiwan). The 10\% acrylamide gel was stained with Coomassie G-250 for approximately $2 \mathrm{~h}$ with a short heating period. Usually, the gels were destained with deionized water for at least $2 \mathrm{~h}$ to achieve adequate contrast. For documentation, the gels were scanned with the printer system Apeos Port IV
(Fuji Xerox, Tokyo, Japan). The samples were analyzed with a series of dilutions from $8 \mu \mathrm{l}$ sample to $22 \mu \mathrm{l} \mathrm{sam-}$ ple in sample buffer. Each time, $15 \mu \mathrm{l}$ of the dilution was loaded in the gel lane.

\section{Western blotting}

For western blotting, the proteins were subjected to SDSPAGE and transferred to polyvinylidene fluoride (PVDF) (Immobilon-P, Merck, Tokyo, Japan) membranes using the Trans-Blot SD Semi-Dry Transfer Cell (Bio-Rad, Tokyo, Japan). Blocking was performed for at least $1 \mathrm{~h}$ with $15 \mathrm{ml} 5 \%$ skim milk in TBS containing 0.1\% Tween 20. After washing with TBS and incubation for at least $2 \mathrm{~h}$ with mouse anti-Strep-tag antibody (1:10,000, QIAGEN, Tokyo, Japan), the blots were rewashed. Incubation with a secondary goat anti-mouse IgG-horseradish peroxidase (HRP) (1:10,000, MBL, Nagoya, Japan) was performed for at least $1 \mathrm{~h}$. Immunoreactive bands were visualized using the Immobilon ECL Ultra Western HRP Substrate (Merck K. K., Tokyo, Japan) on the Versa-Doc 4000 MP (BioRad, Hercules, CA, USA).

\section{Results and discussion \\ Characterization of $\mathrm{Ni}^{2+}$ magnetic nanoparticles}

In this study, 4 types of prepared MNPs (Fig. 1) were designated: $\mathrm{MNPx}, \mathrm{Fe}_{3} \mathrm{O}_{4} @ \mathrm{SiO}_{2}, \mathrm{Fe}_{3} \mathrm{O}_{4} @ \mathrm{SiO}_{2} @ \mathrm{NH}_{2} @$ thin $\mathrm{Ni}$; MNP1, $\mathrm{Fe}_{3} \mathrm{O}_{4} @ \mathrm{SiO}_{2} @ \mathrm{NH}_{2} @$ thick Ni; MNP3, $\mathrm{Fe}_{3} \mathrm{O}_{4} @$ $\mathrm{SiO}_{2} @ \mathrm{NH}_{2} @$ capsule Ni; MNP3.

The MNP surface zeta potential of each step up to the nickel coating was measured (Additional file 1: Fig. S1). The non-functionalized MNPs showed negative charges, and the silica coating and the nickel coating showed a clear positive surface zeta potential. This result clearly indicates the nickel coating on the MNP surface. The conjugation of MNPs by Ni was observed by TEM (Fig. 2a), and EDS was used to analyze each sample for elemental mapping. MNP3 had a capsule-like structure and formed larger particles compared with MNP1 and MNP2. This capsule structure contains many MNPs, as judged from Fe's green signals (Fig. 2a, Fe panel). The capsule structure significantly increased the number of MNPs per Ni particle, which was also proven by the elemental analysis results. In MNP1 and -2, the Fe content relative to the $\mathrm{Ni}$ content was small, and it was presumed that the magnetic force used for protein separation was not enough (1, 2 of Fig. 2b). Since MNP3 maintained a capsule shape, it contained balanced amounts of the element's $\mathrm{Fe}$ and $\mathrm{Ni}$ ( 3 of Fig. 2b). The advantage of MNP3 is that stable magnetic separation could be achieved without the attenuation of the magnetism when a large amount of protein adhered to the particle surface. The hydrodynamic size of the final products, MNP1, 2, and 3, was also measured by 


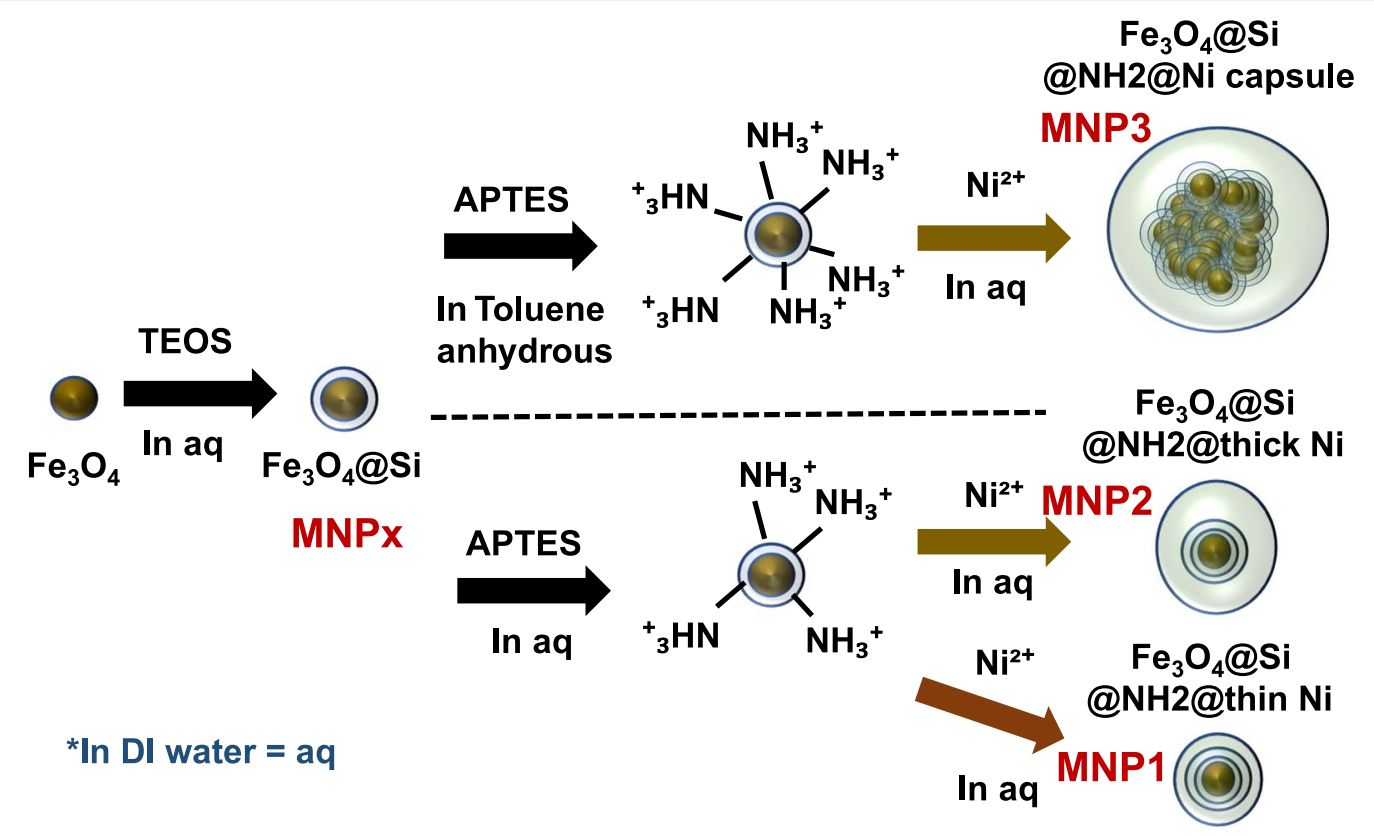

Fig. 1 Three different nickel-modified magnetic nanoparticle synthesis procedures

dynamic light scattering measurements (Additional file 1: Fig. S2). Each functionalized particle shows a different hydrodynamic size, consistent with the size of the particles observed by TEM.

MNP3 was analyzed in detail using HRTEM and high-sensitivity EDS (Fig. 3a, b). The capsule's size was approximately $100 \mathrm{~nm}$ to $200 \mathrm{~nm}$ that fit with the dynamic light scattering measurement result, and the thickness of the Ni capsule that formed to cover the MNP was approximately $20 \mathrm{~nm}$. It was confirmed by EDS elemental mapping that a large amount of Fe was contained in most $\mathrm{Ni}$ capsules. Magnetic separation of MNP3 from the solution was also carried out using a magnet, and MNP3 was separated from the MNP3 solution at a concentration of $10 \mathrm{mg} / \mathrm{ml}$ in $10 \mathrm{~s}$ (Additional file 1: Fig. S3). The detailed analysis has shown that MNP3 has sufficient magnetic force as a nanomaterial for magnetic separation. The His-tagged protein is trapped by the formation of a complex with $\mathrm{Ni}$ on MNPs. When imidazole, which has a higher affinity for metals than histidine, is added, the metal forms a complex with imidazole, which causes the protein-metal complex to detach. This principle is commonly used for affinity purification, whereby low imidazole concentrations can even be used to increase the binding specificity [36]. The His-tagged protein targeted by MNP was treated under different imidazole concentration conditions, and the MNP surface was observed by TEM
(Fig. 3c). It was suggested that many proteins remained adsorbed to the MNPs at an imidazole concentration of $20 \mathrm{mM}$. Since no protein was observed on the surface of MNPs at an imidazole concentration of $1 \mathrm{M}$, it was used as the optimum condition for subsequent experiments.

\section{Preliminary purification comparison tests}

In short, the process of using MNPs for purification involves adding the modified MNPs to the sample solution, which then binds to the target protein, and the complex is then magnetically separated from the surrounding matrix. The matrix is then removed, which is followed by washing and elution steps so that in the end, theoretically, the desired protein is released from the MNPs and is the only protein in the solution (Fig. 4a). MNP1 was then tested using a purified recombinant fluorescent mCherry protein, which can be easily visualized as pinkcolored under UV light. As demonstrated in Fig. 4b, the flow-through had a decreased fluorescence intensity as visualized under UV, indicating that the MNPs were successfully modified with $\mathrm{Ni}$ and showed active binding of His-tagged proteins. Moreover, mCherry signals were also detected from the eluted samples when $500 \mathrm{mM}$ imidazole was used to elute the protein from MNP1 with an approximately $15 \%$ purification recovery rate calculated based on the loading amount. Taken together with the SDS-PAGE and western blotting results (Fig. 4c), these 
a
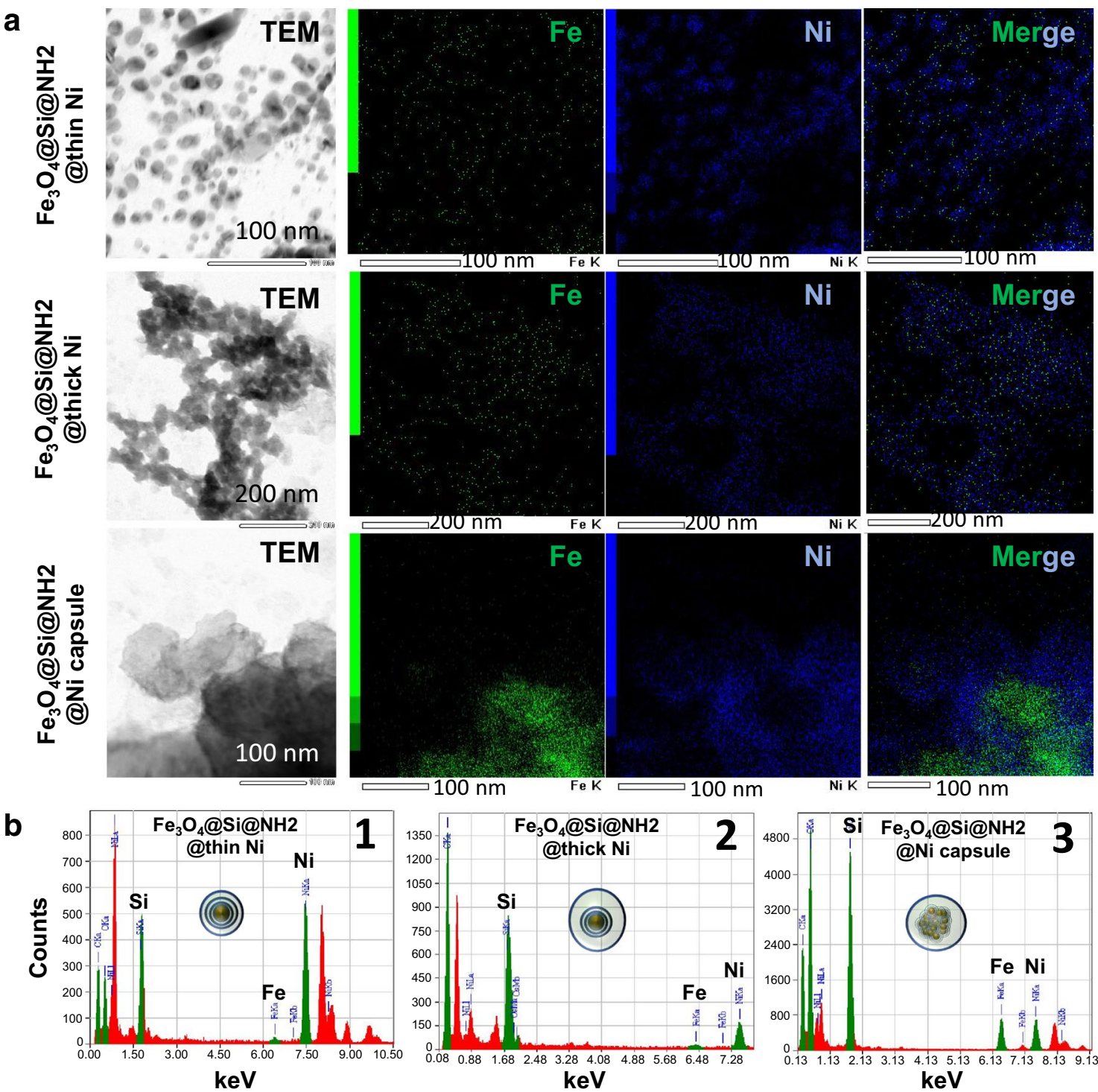

Fig. 2 a Morphology of the three types of magnetic nanoparticles observed by TEM and EDS's elemental mapping results. b Elemental content analysis of each magnetic nanoparticle by EDS. B-1, 2, and 3 indicate MNP1, MNP2, and MNP3, respectively. The Si thin film was modified on the surface of the synthesized MNPs. An amino group was added to the surface of the SI thin film using APTES, and 2-amino benzamide (2-AB) and $\mathrm{Ni}(\mathrm{OAc})_{2}$ were reacted stepwise. Ni was chemically modified on the MNP surface prepared under each condition

results led us to conclude that the prepared MNP1 is usable for purification of His-tagged proteins.

To compare the MNPs prepared in this study, MagneHis magnetic beads and MNP1 were used to purify the SpCaVP1 + EDIII protein from the silkworm fat body. To avoid a high degree of unspecific binding of proteins to the magnetic particles, a low concentration of imidazole was added to the washing buffer: $20 \mathrm{mmol} / \mathrm{l}$ for the particles prepared in this work, and $10 \mathrm{mmol} / \mathrm{l}$ for MagneHis as recommended by the manufacturer. Three hundred $\mathrm{mmol} / \mathrm{l}$ was used for the MagneHis magnetic beads and
$500 \mathrm{mmol} / \mathrm{l}$ imidazole for our MNPs in the first elution buffer, and the second elution buffer contained $1 \mathrm{~mol} / \mathrm{l}$ imidazole in all cases. The SpyTag/-Catcher-linked coexpressed protein has approximately $95 \mathrm{kDa}$, and MNP1 has a low binding affinity for the His-tagged protein in crude protein samples. The MagneHis magnetic beads, in contrast, were able to bind the target protein and to separate it from other proteins, mainly in the first elution fraction (Additional file 1: Fig. S4). Together with our targets, most impurities were eluted from the magnetic beads by $1 \mathrm{~mol} / \mathrm{l}$ imidazole. However, the purified 
a
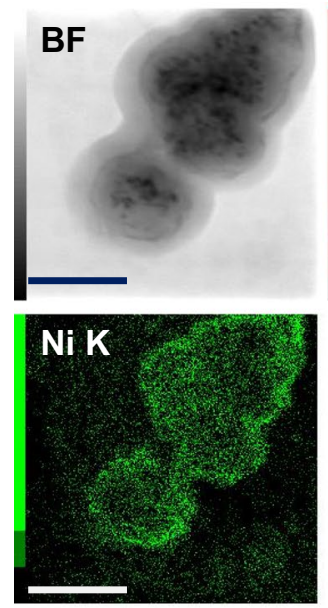
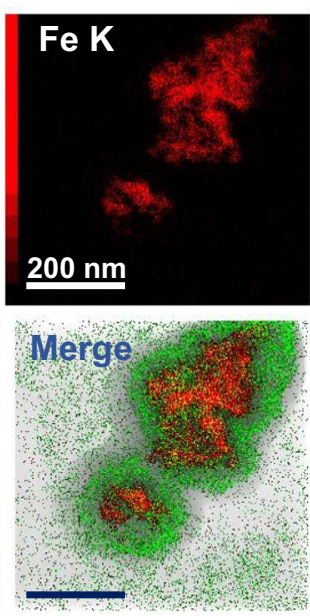

C

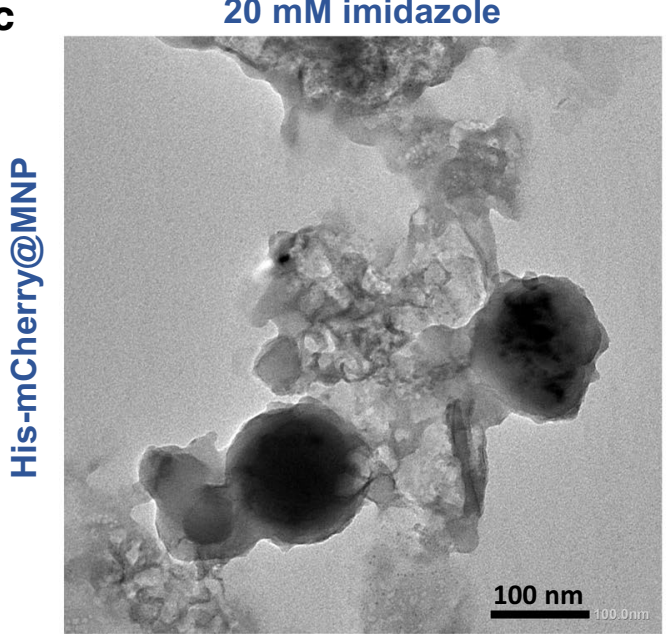

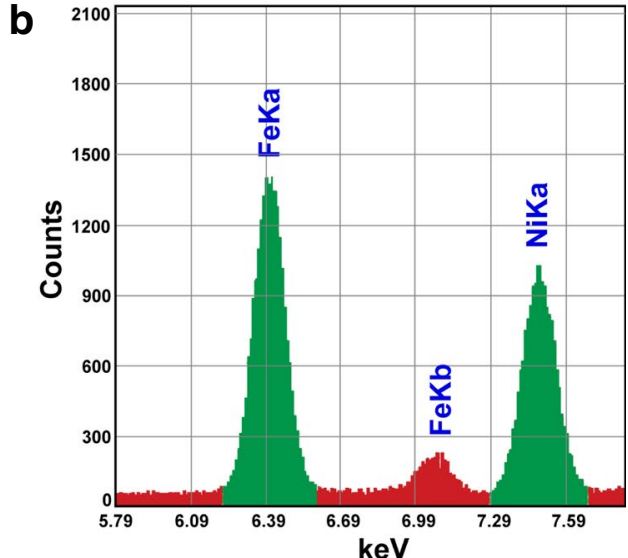

$1 \mathrm{M}$ imidazole

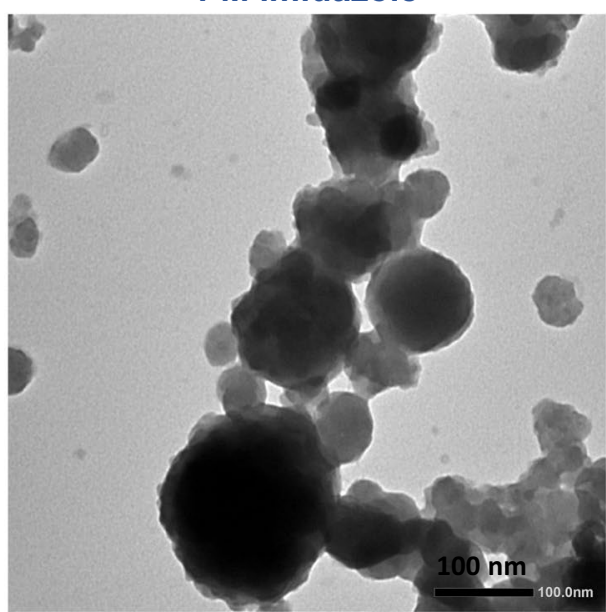

Fig. 3 a TEM image of MNP3 and elemental mapping analysis. b Distribution of nickel and iron content in MNP3. c Images of MNP3 treated with different concentrations of imidazole after magnetic separation

proteins were still at a very low concentration. They were not visible after Coomassie staining (Additional file 1: Fig. S4), even when the MagneHis MNPs were used on a large purification scale (Additional file 1: Fig. S5). The reason was not further investigated; one main reason could be that the magnetic beads' loading capacity is with $5 \mu \mathrm{g}$ Ubiquitin/mg MNP not very high. Incomplete elution could be ruled out, as shown in Additional file 1: Fig. S4.

The above negative results raised whether the protein sample from the silkworm fat body as a sample matrix is too difficult to purify for the proof-of-concept. Therefore, purification was then repeated with the $E$. coli cell lysate containing a His-tagged mCherry protein as a model sample. One additional benefit of using mCherry is the intense red fluorescence (Ex. 540-590 nm, Em. 550$650 \mathrm{~nm}$ ) and the red color, which makes the protein's tracking during the purification process easier. Using this sample matrix and model protein, MNP1 and MNP2 were able to bind and separate mCherry from the host cell proteins (Additional file 1: Fig. S6A-B). MNP2 was more effective than MNP1 because of the reduced nonspecific binding of the target protein to the MNP itself, as it could not be eluted from the MNP (Additional file 1: Fig. S6B). Moreover, the protein amount in the MNP2 elution fraction was higher than that in the MNP1 elution fraction (Additional file 1: Fig. S6B), which was also observable by fluorescence, as the red fluorescence of elution fraction 1 (E1) from MNP2 was much stronger than that from MNP1 (Additional file 1: Fig. S6C).

\section{Ni-modified highly dispersible MNPs}

During the purification process, illustrated in Fig. 5a, the previously prepared MNPs tended to aggregate easily 


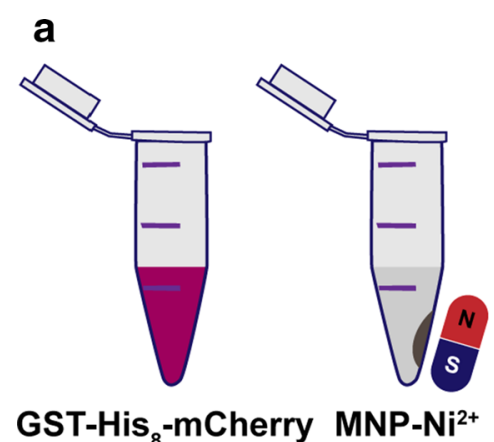

GST-His $_{8}-$ mCherry MNP-Ni2+

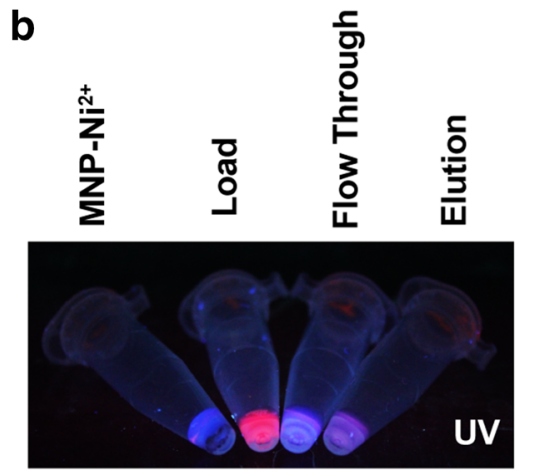

GST-His $_{8}$-mCherry
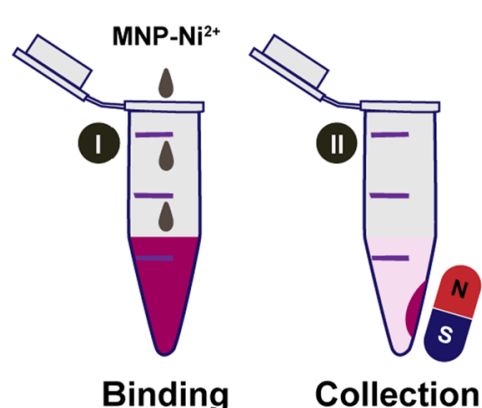

Collection

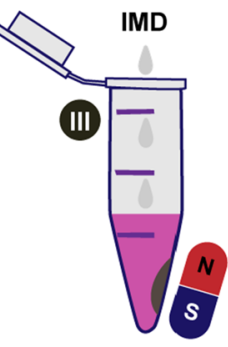

Elution

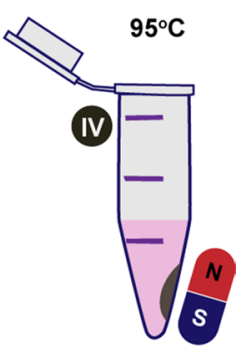

Boiled

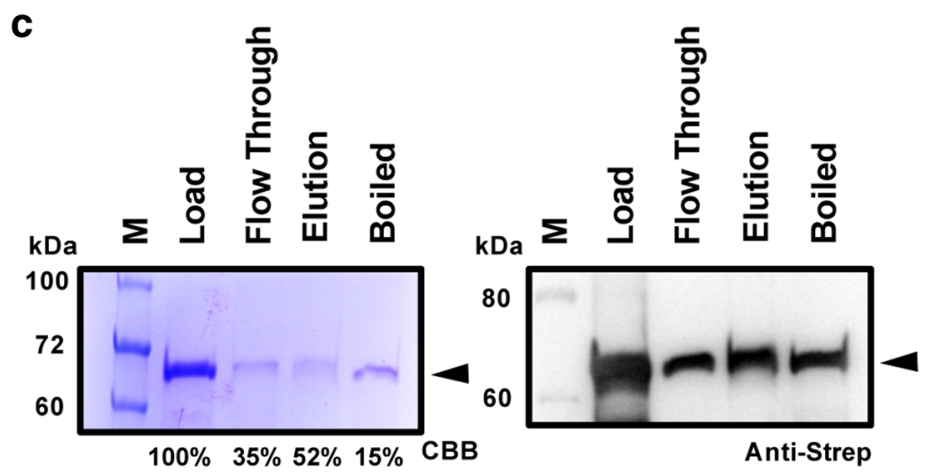

Fig. 4 Preliminary binding test of the GST-His8-mCherry protein purified using MNP1. a Schematic diagram of protein separation using MNP1. A protein of interest such as GST-His - -mCherry (red) was employed for protein-MNP capture, and the released mCherry protein could be visualized by UV detection during the whole process. The study was simply performed by allowing the protein to bind (I) and to be collected by a magnet (II), followed by washing and elution (III). The remaining bound protein on the MNPs was denatured by heating $\left(95^{\circ} \mathrm{C}, 10 \mathrm{~min}\right)$ in SDS-PAGE loading buffer (IV). b Bare MNP1, loading, flow-through, and elution samples were illuminated under UV light. (C) MNP1 allowed efficient single-step purification as proven by SDS-PAGE (left) and western blot analysis using Anti-Strep-tag II (right)

and stick to the tube walls during the purification process. This complicated the whole purification process and increased protein loss, which reduced the recovery of the target proteins. Our magnetic nanoparticles were further improved to be more easily dispersed in aqueous solutions to tackle these problems. MNP3 was then also tested for use in purification because of its high dispersibility. The purification result from E. coli extract is shown in Fig. 5b. Using MNP3 for comparison, the previous mCherry purification process was repeated, during which the sample amount was slightly increased from 250 to $300 \mu \mathrm{l}$, and the MNP amount was somewhat reduced from 350 to $300 \mu \mathrm{l}$ of a $2 \mathrm{mg} / \mathrm{ml}$ MNP solution. The purification results for MNP3 were better than those for MNP2. Not only was nonspecific binding decreased significantly, but the amount of the eluted target protein was also increased compared to that eluted from MNP2, and the specificity of the eluted proteins improved, as shown by the western blotting results (Additional file 1: Fig. S7A-C). The decrease in nonspecific binding and the improved elution ability were also visible on the CBBstained western blotting membrane; therefore, on the latter membrane, a strong band for the target protein mCherry was visible (Additional file 1: Fig. S7A). On the other hand, the fluorescence assay and western blotting results show that compared to binding to MNP2, a large amount of the target protein could not bind strongly enough to MNP3 and was present in the washing fractions (Additional file 1: Fig. S7B-C). This is also supported by the samples' fluorescence emission obtained from the different purification steps (Additional file 1: Fig. S7C).

\section{Purification of protein from a complex sample matrix using MNP3}

After proving the functionality of MNP3, the purification of His-tagged SpCaVP1+EDIII was performed from the silkworm fat body. The protocol was similar to that used for MNP1 and MNP2. The significant changes were the increase in the MNP amount (from $100 \mu \mathrm{l}$ to $500 \mu \mathrm{l}$ $2 \mathrm{mg} / \mathrm{ml}$ solution) and $1 \mathrm{~mol} / \mathrm{l}$ imidazole instead of only $300 \mathrm{mmol} / \mathrm{l}$ the first elution. This time, the recombinant protein was separated successfully with the MNP3, and most target proteins were already eluted in the first step 


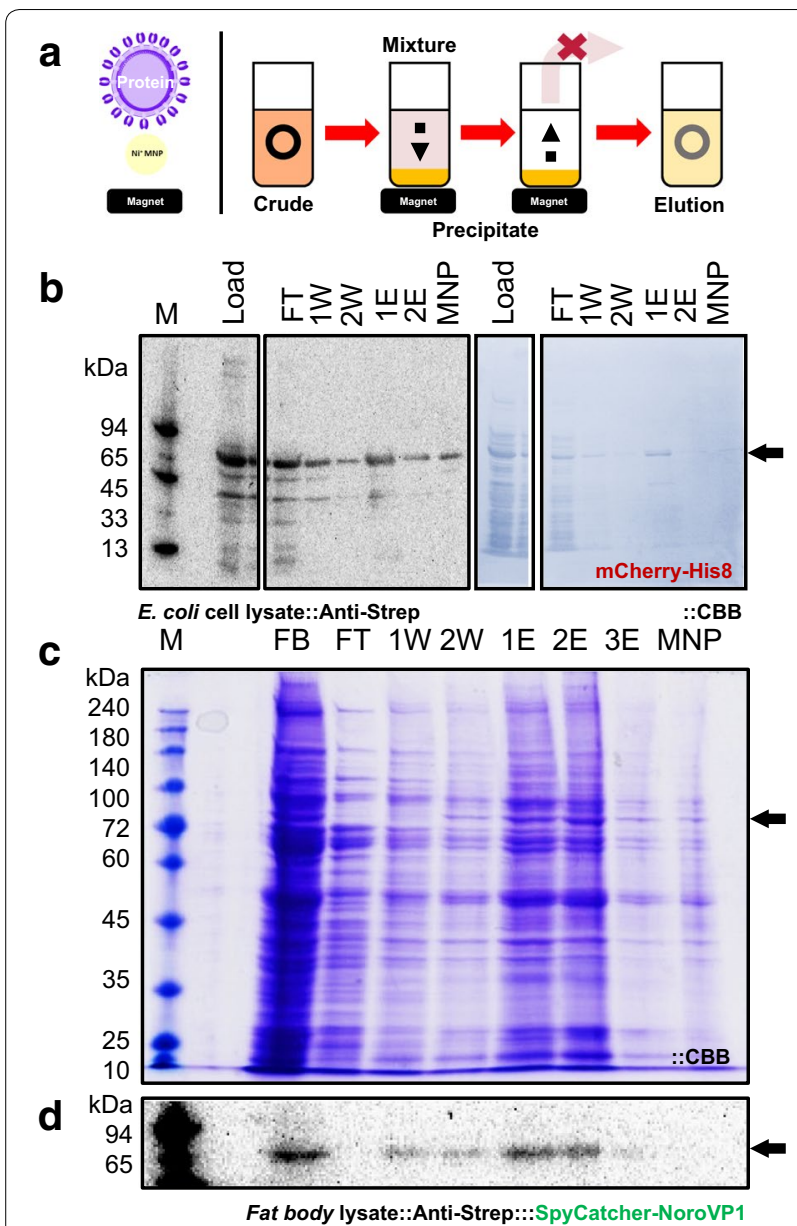

Fig. 5 Purification of proteins from the fat body of silkworms with MNP3. a Principle of MNP purification. MNPs bind to target proteins, both are separated from impurities via a magnet, and the supernatant is discarded. After removing the magnet, the target protein-bound MNPs are resuspended (e.g., in elution buffer). b Western blot and CBB-stained membrane of His-tagged mCherry protein purified using MNP3. The elution was performed with $50 \mu \mathrm{l}$ of $1 \mathrm{~mol} / \mathrm{l}$ imidazole. The sample was diluted in a volume of $8 \mu \mathrm{l}$ to $22 \mu \mathrm{l}$, and in each lane, $15 \mu \mathrm{l}$ was loaded. c Optimized and scaled-up (1 ml sample) purification of proteins from the fat body of the silkworm with MNP3 shown by Coomassie blue-stained SDS-PAGE (c) and western blotting results (d) of VP1 purification using MNP3. For both, the washing buffer contained $20 \mathrm{mmol} / \mathrm{l}$ imidazole, with $1 \mathrm{ml}$ fat body and $7.5 \mathrm{mg}$ MNPs. The first elution was performed with $300 \mathrm{mmol} / \mathrm{l}$, and the second and third elution was performed with $1 \mathrm{~mol} / \mathrm{l}$ imidazole (500 $\mu \mathrm{l}$ each). An $8 \mu \mathrm{l}$ to $22 \mu \mathrm{l}$ dilution was performed, and $15 \mu \mathrm{l}$ was loaded in each lane FB: Fat body; FT: Flow-through; W1: 1st Washing fraction; W2: 2nd Washing fraction; E1: 1st Elution fraction; E2: 2nd Elution fraction; MNP: MNPs; M: Marker; Black arrow indicates the target protein

so that only a small loss occurred due to strong binding to the MNPs (Additional file 1: Fig. S8), which was also assessed by comparison to the results obtained using mCherry as the sample (Additional file 1: Fig. S7). On the other hand, using $1 \mathrm{~mol} / \mathrm{l}$ imidazole directly as the first elution buffer proved to be disadvantageous. Even if the western blot band corresponding to the target protein was intense, the band could not be clearly distinguished from that of the eluted nonspecifically bound host cell proteins. This is different from the previous result, where the target protein comprised the main protein band, and few impurities were detectable (Additional file 1: Fig. S7A).

Nevertheless, the efficiency of MNP3 for the purification of recombinant proteins from a complex matrix was proven, as a high protein recovery could be achieved. Especially as we already showed in other studies that high purity and high recovery by simultaneous high host cell reduction from the silkworm system is very challenging so far $[12,13]$. On the other hand, the purification is promising, but not satisfying enough.

Therefore, this protocol was scaled up with a SpCaVP1 sample amount of $1 \mathrm{ml}$ fat body, $4.6 \mathrm{mg}$ MNPs, $300 \mathrm{mmol} / \mathrm{l}$ imidazole as the first elution step, and the last two elution's were performed with $1 \mathrm{~mol} / \mathrm{l}$ imidazole. The elution was performed with a volume of $500 \mu \mathrm{l}$, which led to the concentration of the target protein VP1. However, the loss of VP1 increased significantly during the washing steps, which consisted of $500 \mu \mathrm{l} 20 \mathrm{mmol} / \mathrm{l}$ imidazole (Additional file 1: Fig. S9). To tackle this issue, the protocol was changed by removing imidazole from the washing buffer but not from the buffer used for the initial incubation and by increasing the MNP amount. This resulted in high VP1 recovery by reducing loss via washing and direct binding to the MNPs. As a result, the nonspecific binding to the MNPs increased (Additional file 1: Fig. S10), which was greater than expected. As the recovery also significantly improved, it was hypothesized that both effects were affected by the MNP amount.

To test this and decrease the unspecific binding, the protocol was again optimized by reintroducing $20 \mathrm{mmol} / \mathrm{l}$ imidazole to the washing buffer and increasing the MNP amount to $7.5 \mathrm{mg}$. This resulted in a similar high recovery of VP1 but also in a surprisingly high level of nonspecific binding to the MNP3s, even if it was slightly better than the previous (Fig. 5c, d). This leads to the hypothesis that proteins are easily bound to MNPs because of the large amount of histidine residues in proteins and that proteins from the silkworm fat body have a strong affinity for MNPs. However, proteins from the E. coli cell extract did not show this kind of behavior, as previously described (Additional file 1: Fig. S7A). It is a known fact that other proteins as the target proteins show affinity to the separation matrix, especially from eucaryotic systems, and His-tag affinity protocols take this into account [36]. Based on the imaging software results, by using the supposed target protein bands from the CBB staining and protein assay, we estimated roughly that we were able to reduce the protein amount in elution fractions 1 and 2 by 
approximately $77.7 \%$, and the recovery ratio of VP1 was estimated to be $50.8 \%$. This result is not a completely perfect purification as it is usually desired: One step, no target protein lost, and high purity. However, this is a rare result in reality. Our result is an additional useful method as a pretreatment before further chromatography steps to significantly reduce the host protein amount. This is especially interesting, as already shown. First, good separation and purity with our target protein from the E. coli extract were achieved (Fig. 5b), and second, a good protein reduction from the silkworm fat body matrix was achieved. The latter one is very intriguing, as the purification from this eucaryotic system is still troublesome and a big limitation for this system's usage. We reviewed the problems of the silkworm purification already elsewhere [7] and also showed that the purification is indeed not easy $[12,13]$. Therefore, we will not discuss this aspect exhaustively any further. Another aspect that has to be mentioned is that the purification protocol still has room for further optimization as shown with our results, especially the time aspect, but this was not inside the scope of this present work and is under ongoing investigations.

Furthermore, the binding behavior of the MNP3s were investigated using mCherry as a reference and BSA as a negative control, which should not be able to bind specifically to the MNPs. With TEM, sample incubation was investigated with MNP3s after the magnetic separation and removal of the supernatant. After the two washing steps, the elution solution contained MNPs, $1 \mathrm{~mol} / \mathrm{l}$ imidazole buffer, and in some cases, the sample (Additional file 1: Fig. S11). These images show that mCherry is explicitly bound to the MNPs and was released by the elution buffer (Additional file 1: Fig. S11A-B). However, it is also clear that BSA has a high nonspecific affinity for the MNPs, clustered around the MNP3s. Nevertheless, it was removed later after the elution step, as only a small amount was visible in the TEM images after elution (Additional file 1: Fig. S11C-D). This supports the conclusion that our MNP3s are a promising tool for pretreatment to reduce impurities before further purification procedures.

\section{Binding study of MNP3 with a highly efficient $\mathrm{NH}_{2}$ coating} Using mCherry prepurified via the Strep-tag affinity column, we intended to perform a binding study with the MNP3s. For this, a purified mCherry sample $(120 \mu \mathrm{g} /$ $\mathrm{ml}$ protein) with several different volumes was added to achieve a different loading amount (12 $\mu \mathrm{g} ; 30 \mu \mathrm{g} ; 48 \mu \mathrm{g}$; $60 \mu \mathrm{g} ; 72 \mu \mathrm{g} ; 84 \mu \mathrm{g} ; 96 \mu \mathrm{g}$; or $108 \mu \mathrm{g})$ in $300 \mu \mathrm{l} \mathrm{MNP3}$ solution $(2 \mathrm{mg} / \mathrm{ml})$, and the buffer volume was adjusted to $950 \mu \mathrm{l}$ or $1.2 \mathrm{ml}$ each time. Except for the prepurified mCherry sample with $120 \mu \mathrm{g}$ protein $/ \mathrm{ml}$, the protein concentration could not be determined for any other sample with the Pierce BCA Protein Assay Kit (Thermo
Scientific, Waltham, USA) or the BioRad Protein Assay (BioRad, Hercules, CA, USA) because of the interaction with imidazole and the very low protein concentration. Moreover, the small sample amount made it impossible to dialyze the sample after elution. Therefore, we tried to solve this issue using the intensity of the western blot bands as a reference (Additional file 1: Fig. S12). Unfortunately, the western blot bands were too unstable and inconsistent to be analyzed and calculated with the imaging software.

Nevertheless, these results already indicated several things. With an increase in the loaded protein amount, the loss in the flow-through fractions remained mostly the same, but the amount that could be eluted or was still bound to the MNPs increased significantly (Additional file 1: Fig. S12A). Protein was still bound to the MNPs, despite using a strong elution buffer with $1 \mathrm{~mol} / \mathrm{l}$ imidazole. This raises two possibilities. Elution of the nickel MNPs is imidazole-dependent and concentration-dependent in terms of the already eluted amount of protein in the surrounding buffer. The other possibility is that the amount of bound target protein is very high. The relative amount of imidazole in the elution buffer used is too low to compete with all binding sites, despite the concentration of $1 \mathrm{~mol} / \mathrm{l}$. Therefore, with the highest amount of loaded protein, the second elution fraction also contained a high amount of target protein, which was not the case for the lower amount (Additional file 1: Fig. S12A). In the subsequent experiments, when more target protein was loaded, more of the protein was recoverable. The highest minimum binding capacity was $48.8 \mu \mathrm{g} / \mathrm{mg} \mathrm{MNP}$, and the minimum elution capability was $26.43 \mu \mathrm{g} / \mathrm{mg}$ MNP (data not shown). However, using imaging software to assess the CBB-stained protein bands for the elution (Additional file 1: Fig. S12B) and MNP fractions proved to be unreliable, and therefore, a qualitative approach was undertaken.

By loading three different amounts of purified mCherry $(10 \mu \mathrm{g} ; 50 \mu \mathrm{g}$; and $100 \mu \mathrm{g})$ and analyzing the western blotting results for the flow-through revealed that $0.6 \mathrm{mg}$ MNP3s could bind at a minimum approximately $50 \mu \mathrm{g}$ mCherry (Fig. 6). This is the binding capacity of approximately $83.3 \mu \mathrm{g} / \mathrm{mg}(50 \mu \mathrm{g} / 0.6 \mathrm{mg}) \mathrm{MNP}$. The result also indicates that the binding capacity maybe even higher (little lower than $100 \mu \mathrm{g} / 0.6 \mathrm{mg}=166.7 \mu \mathrm{g} / \mathrm{mg} \mathrm{MNP}$ ), as the western blotting results for FT3 were not considerably better than those for FT2 (Fig. 6). This could be due to the higher binding of the target protein at a higher concentration. Therefore, we showed that our MNP has a higher binding capacity than the commercial MagneHis particles used. A minimum binding capacity of approximately $83.3 \mu \mathrm{g} / \mathrm{mg} \mathrm{MNP}$, a release of approximately $50 \%$, and with VP1, a recovery of about $50.8 \%$; based on the company analysis certificate, the binding 


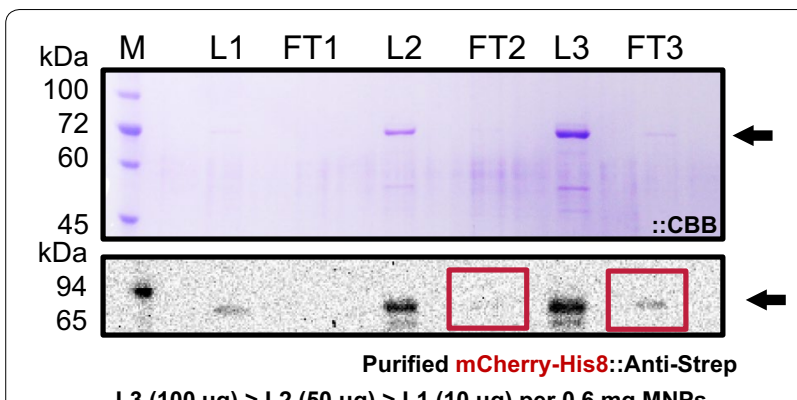

L3 $(100 \mu \mathrm{g})>$ L2 $(50 \mu \mathrm{g})>$ L1 $(10 \mu \mathrm{g})$ per $0.6 \mathrm{mg}$ MNPs

Fig. 6 Binding study of the MNP3s. The capability of $0.6 \mathrm{mg}$ MNPs to bind $10 \mu \mathrm{g}, 50 \mu \mathrm{g}$, or $100 \mu \mathrm{g}$ mCherry. Coomassie blue staining and western blotting results. FT: Flow-through; W1: 1st Washing fraction; W2: 2nd Washing fraction; E1: 1st Elution fraction; E2: 2nd Elution fraction; MNP: MNPs; L1-3: Prepurified loaded samples with the same target protein concentration but different amounts; M: Marker; black arrows indicate the target protein; red boxes indicate the corresponding western blot bands

capacity of the commercial MagneHis is $5 \mu \mathrm{g}$ Ubiquitin/mg MNP with a minimum release of $50 \%$.

Furthermore, ubiquitin's molecular mass is approximately $8.6 \mathrm{kDa}$, and that of mCherry is $72.2 \mathrm{kDa}$. If we assume that the size is correlated with the mass, we can say that our model protein larger than ubiquitin. Although it is impossible to give an exact quantitative comparison, our binding capacity is an eightfold higher than that of MagneHis.

\section{Conclusion and outlook}

A successful purification method was developed for Histagged proteins using our prepared MNPs. Moreover, these MNPs can be easily synthesized and can purify the target protein from complex sample matrices. In terms of recovery and binding capacity, these MNPs had a higher capacity than the commercial MagneHis that used for comparison. However, this was only valid for one of the three different MNPs, which was further investigated. The most efficient type was MNP3, which has a size of $100 \mathrm{~nm}$ to $200 \mathrm{~nm}$ and has an approximately $20 \mathrm{~nm}$-thick nickel covering. By EDS elemental mapping, a large amount of Fe inside the MNP3s was confirmed, which provided their magneticity. Using the MNP3s, the total protein amount in the elution fractions was reduced up to at least approximately $77.7 \%$ with a target protein recovery of $50.8 \%$ from the silkworm fat body. The fat body is a complex sample matrix. It contains a large amount of proteins and many different kinds of proteins and lipids, which cannot be easily separated during prior treatment. However, with our MNP3s, we could highly reduce the amount of impurities from the silkworm fat body matrix. Using a pretreatment step should improve the overall purity and recovery of recombinant proteins from the silkworm. The binding capacity of pure mCherry could be estimated to be at least $83.3 \mu \mathrm{g}$ protein $/ \mathrm{mg} \mathrm{MNP}$ as the minimum binding capacity, with a target protein recovery of approximately $50.8 \%$. The protein used to determine the binding capacity has an approximately eightfold higher mass, indicating that the MNPs have an even higher binding capacity than the commercial particles. We conclude that MNP3 is a suitable candidate for further investigations and simple purifications in laboratories, especially as a pretreatment step for complex sample matrices, such as the silkworm expression system.

\section{Additional file}

Additional file 1. Additional figures S1-S12.

\section{Acknowledgements \\ Not applicable}

\section{Authors' contributions}

RM performed the experiments, wrote the manuscript, and participated in study design. KT prepared the MNPs and characterized them. JX designed the main part of the study and performed recombinant protein expression. JB provided purification material and related support. HW supervised part of the project and revised the manuscript. EYP supervised the entire project, funding, and revised the manuscript. All authors read and approved the final manuscript.

\section{Funding}

This work was funded by the JSPS KAKENHI Grant-in-Aid for Exploratory Research No. 16K14900 and the JSPS KAKENHI Grant-in-Aid for Scientific Research (A) No. $20 \mathrm{H} 00411$.

\section{Availability of data and materials}

All relevant data generated or analyzed during this study are included in this published article and its Additional file 1. The missing datasets used and/ or analyzed during the current study are available from the corresponding author upon reasonable request.

\section{Ethics approval and consent to participate}

Not applicable.

\section{Consent for publication}

Not applicable.

\section{Competing interests}

All authors declare that they have no competing interests.

\section{Author details \\ ${ }^{1}$ Department of Bioscience, Graduate School of Science and Technol- ogy, Shizuoka University, 836 Ohya, Suruga-ku, Shizuoka 422-8529, Japan. ${ }^{2}$ Institute of Medicinal and Pharmaceutical Chemistry, TU Braunschweig, Beethovenstr. 55, 38106 Braunschweig, Germany. ${ }^{3}$ Laboratory of Biotechnol- ogy, Green Chemistry Research Division, Research Institute of Green Science and Technology, Shizuoka University, 836 Ohya, Shizuoka 422-8529, Japan. ${ }^{4}$ Institute of Biology and Information Science, Biomedical Synthetic Biology Research Center, School of Life Sciences, East China Normal University, Shang- hai 200062, People's Republic of China.}

Received: 29 August 2020 Accepted: 21 October 2020 Published online: 06 November 2020

References

1. Demain $A L$, Vaishnav P. Production of recombinant proteins by microbes and higher organisms. Biotechnol Adv. 2009;27:297-306. https://doi.org/10.1016/j.biotechadv.2009.01.008. 
2. Kato T, Kajikawa M, Maenaka K, Park EY. Silkworm expression system as a platform technology in life science. Appl Microbiol Biotechnol. 2010;85:459-70. https://doi.org/10.1007/s00253-009-2267-2.

3. Miyajima A, Schreurs J, Otsu K, Kondo A, Aral K-I, Maeda S. Use of the silkworm, Bombyx mori, and an insect baculovirus vector for high-level expression and secretion of biologically active mouse interleukin-3. Gene. 1987;58:273-81. https://doi.org/10.1016/0378-1119(87)90382-9.

4. Mitsudome T, Xu J, Nagata Y, Masuda A, liyama K, Morokuma D, et al. Expression, purification, and characterization of endo-beta-Nacetylglucosaminidase $\mathrm{H}$ using baculovirus-mediated silkworm protein expression system. Appl Biochem Biotechnol. 2014;172:3978-88. https ://doi.org/10.1007/s12010-014-0814-5.

5. Pietrzyk AJ, Bujacz A, Lochynska M, Jaskolski M, Bujacz G. Isolation, purification, crystallization and preliminary $X$-ray studies of two $30 \mathrm{kDa}$ proteins from silkworm haemolymph. Acta Crystallogr Sect F Struct Biol Cryst Commun. 2011;67:372-6. https://doi.org/10.1107/S1744 309110054564.

6. Molinari P, Peralta A, Taboga O. Production of rotavirus-like particles in Spodoptera frugiperda larvae. J Virol Methods. 2008;147:364-7. https:// doi.org/10.1016/j.jviromet.2007.09.002

7. Minkner R, Park EY. Purification of virus-like particles (VLPS) expressed in the silkworm Bombyx mori. Biotechnol Lett. 2018;40:659-66. https:// doi.org/10.1007/s10529-018-2516-5.

8. Targovnik A, Arregui M, Bracco L, Urtasun N, Baieli M, Segura M, et al. Insect larvae: a new platform to produce commercial recombinant proteins. CPB. 2016;17:431-8. https://doi.org/10.2174/1389201017 05160303163947.

9. Deo VK, Tsuji Y, Yasuda T, Kato T, Sakamoto N, Suzuki H, Park EY. Expres sion of an RSV-gag virus-like particle in insect cell lines and silkworm larvae. J Virol Methods. 2011;177:147-52. https://doi.org/10.1016/j.jviro met.2011.07.012.

10. Dong J, Harada M, Yoshida S, Kato Y, Murakawa A, Ogata M, et al. Expression and purification of bioactive hemagglutinin protein of highly pathogenic avian influenza $\mathrm{A}(\mathrm{H} 5 \mathrm{~N} 1)$ in silkworm larvae. J Virol Methods. 2013;194:271-6. https://doi.org/10.1016/j.jviro met.2013.08.040.

11. Sviben D, Forcic D, Ivancic-Jelecki J, Halassy B, Brgles M. Recovery of infective virus particles in ion-exchange and hydrophobic interaction monolith chromatography is influenced by particle charge and totalto-infective particle ratio. J Chromatogr B Analyt Technol Biomed Life Sci. 2017;1054:10-9. https://doi.org/10.1016/j.jchromb.2017.04.015.

12. Minkner R, Xu J, Zagst H, Wätzig H, Kato T, Oltmann-Norden I, Park EY A systematic and methodical approach for the efficient purification of recombinant protein from silkworm larval hemolymph. J Chromatogr B Analyt Technol Biomed Life Sci. 2019;1138:121964. https://doi. org/10.1016/j.jchromb.2019.121964.

13. Minkner R, Baba R, Kurosawa Y, Suzuki S, Kato T, Kobayashi S, Park EY. Purification of human papillomavirus-like particles expressed in silkworm using a Bombyx mori nucleopolyhedrovirus bacmid expression system. J Chromatogr B Analyt Technol Biomed Life Sci. 2018;1096:3947. https://doi.org/10.1016/j.jchromb.2018.08.007.

14. Nosrati H, Salehiabar M, Davaran S, Ramazani A, Manjili HK, Danafar $\mathrm{H}$. New advances strategies for surface functionalization of iron oxide magnetic nano particles (IONPS).

15. Krishnan KM. Biomedical nanomagnetics: a spin through possibilities in imaging, diagnostics, and therapy. IEEE Trans Magn. 2010;46:2523-58. https://doi.org/10.1109/TMAG.2010.2046907.

16. Singh N, Jenkins GJS, Asadi R, Doak SH. Potential toxicity of superparamagnetic iron oxide nanoparticles (SPION). Nano Rev. 2010. https://doi. org/10.3402/nano.v1i0.5358.

17. Mehta RV. Synthesis of magnetic nanoparticles and their dispersions with special reference to applications in biomedicine and biotechnology. Mater Sci Eng C Mater Biol Appl. 2017;79:901-16. https://doi. org/10.1016/j.msec.2017.05.135.

18. Safarik I, Safarikova M. Magnetic nano- and microparticles in biotechnology. Chem Pap. 2009;63:301. https://doi.org/10.2478/s1169 6-009-0054-2.

19. Wang Y, Zhang M, Wang L, Li W, Zheng J, Xu J. Synthesis of hierarchical nickel anchored on Fe 304 @SiO 2 and its successful utilization to remove the abundant proteins $(\mathrm{BHb})$ in bovine blood. New J Chem 2015;39:4876-81. https://doi.org/10.1039/C5NJ00241A.
20. Hu Y, Mignani S, Majoral J-P, Shen M, Shi X. Construction of iron oxide nanoparticle-based hybrid platforms for tumor imaging and therapy. Chem Soc Rev. 2018;47:1874-900. https://doi.org/10.1039/c7cs00657h.

21. Mierczynska-Vasilev A, Mierczynski P, Maniukiewicz W, Visalakshan RM, Vasilev K, Smith PA. Magnetic separation technology: Functional group efficiency in the removal of haze-forming proteins from wines. Food Chem. 2019;275:154-60. https://doi.org/10.1016/j.foodc hem.2018.09.046.

22. Oz Y, Abdouni Y, Yilmaz G, Becer CR, Sanyal A. Magnetic glyconanoparticles for selective lectin separation and purification. Polym Chem. 2019;10:3351-61. https://doi.org/10.1039/C8PY01748D.

23. Ta DT, Vanella R, Nash MA. Magnetic separation of elastin-like polypeptide receptors for enrichment of cellular and molecular targets. Nano Lett. 2017;17:7932-9. https://doi.org/10.1021/acs.nanolett.7b04318.

24. Schwaminger SP, Blank-Shim SA, Scheifele I, Pipich V, Fraga-García P, Berensmeier S. Design of interactions between nanomaterials and proteins: a highly affine peptide tag to bare iron oxide nanoparticles for magnetic protein separation. Biotechnol J. 2019;14:e1800055. https ://doi.org/10.1002/biot.201800055.

25. Jose L, Lee C, Hwang A, Park JH, Song JK, Paik H-J. Magnetically steerable Fe3O4@Ni2+-NTA-polystyrene nanoparticles for the immobilization and separation of his6-protein. Eur Polym J. 2019;112:524-9. https ://doi.org/10.1016/j.eurpolymj.2019.01.024.

26. Schwaminger SP, Fraga-García P, Blank-Shim SA, Straub T, Haslbeck M, Muraca F, et al. Magnetic one-step purification of his-tagged protein by bare iron oxide nanoparticles. ACS Omega. 2019;4:3790-9. https://doi. org/10.1021/acsomega.8b03348.

27. Chang M, Qin Q, Wang B, Xia T, Lv W, Sun X, et al. Carboxymethylated polyethylenimine modified magnetic nanoparticles specifically for purification of His-tagged protein. J Sep Sci. 2019;42:744-53. https:// doi.org/10.1002/jssc.201800969.

28. Rashid Z, Naeimi H, Zarnani A-H, Mohammadi F, Ghahremanzadeh R. Facile fabrication of nickel immobilized on magnetic nanoparticles as an efficient affinity adsorbent for purification of his-tagged protein. Mater Sci Eng C Mater Biol Appl. 2017;80:670-6. https://doi. org/10.1016/j.msec.2017.07.014.

29. Zhou Y, Yan D, Yuan S, Chen Y, Fletcher EE, Shi H, Han B. Selective binding, magnetic separation and purification of histidine-tagged protein using biopolymer magnetic core-shell nanoparticles. Protein Expr Purif. 2018;144:5-11. https://doi.org/10.1016/j.pep.2017.11.004.

30. Xu J, Kato T, Park EY. Development of SpyTag/SpyCatcher-Bacmid Expression Vector System (SpyBEVS) for protein bioconjugations inside of silkworms. Int J Mol Sci. 2019. https://doi.org/10.3390/ijms20174228.

31. Suhaimi H, Hiramatsu R, Xu J, Kato T, Park EY. Secretory Nanoparticles of neospora caninum profilin-fused with the transmembrane domain of GP64 from silkworm hemolymph. Nanomaterials (Basel). 2019. https:// doi.org/10.3390/nano9040593.

32. Massart R. Preparation of aqueous magnetic liquids in alkaline and acidic media. IEEE Trans Magn. 1981;17:1247-8. https://doi. org/10.1109/TMAG.1981.1061188.

33. Kralj S, Makovec D, Čampelj S, Drofenik M. Producing ultra-thin silica coatings on iron-oxide nanoparticles to improve their surface reactivity. J Magn Magn Mater. 2010;322:1847-53. https://doi.org/10.1016/j. jmmm.2009.12.038.

34. Keshtkar M, Shahbazi-Gahrouei D, Mehrgardi MA, Aghaei M, Khoshfetrat SM. Synthesis and cytotoxicity assessment of gold-coated magnetic iron oxide nanoparticles. J Biomed Phys Eng. 2018;8:357-64.

35. Rashid Z, Naeimi H, Zarnani A-H, Nazari M, Nejadmoghaddam M-R, Ghahremanzadeh R. Fast and highly efficient purification of $6 \times$ histidinetagged recombinant proteins by Ni-decorated MnFe $204 @$ @iO 2 @NH 2 @2AB as novel and efficient affinity adsorbent magnetic nanoparticles. RSC Adv. 2016;6:36840-8. https://doi.org/10.1039/C5RA25949E.

36. Spriestersbach A, Kubicek J, Schäfer F, Block H, Maertens B. Purification of his-tagged proteins. Meth Enzymol. 2015;559:1-15. https://doi. org/10.1016/bs.mie.2014.11.003.

\section{Publisher's Note}

Springer Nature remains neutral with regard to jurisdictional claims in published maps and institutional affiliations. 